\title{
THE CHEMICAL COMPOSITION AND THE ANTIMICROBIAL PROPERTIES OF THE ESSENTIAL OIL EXTRACTED FROM THE LEAVES OF TEUCRIUM CAPITATUM L.
}

\author{
JALILA EL AMRI*, KHALID EL BADAOUI, ZOUBIDA HALOUI
}

Department of Biology, Laboratory of the Environment and Health, The Faculty of Sciences, University of Moulay Ismail, BP 11201 Zitoune, Meknes, Morocco. Email: jalilaelamri83@gmail.com

Received: 04 August 2016, Revised and Accepted: 22 October 2016

\begin{abstract}
Objective: In the framework of the search for new biological molecules, an ethnobotanical study has been carried out in the region of El Hajeb in Morocco in the interest of will select the data ethnopharmacological on medicinal and aromatic plants and on the découveres new principles assets. On the basis of a questionnaire prepared, a survey was conducted of the local population where we find a close relation which exists between the plant species described in the said region and the different types of diseases affecting the human being; six plants have been chosen to evaluate the antifungal activity of essential oils against the bacterial strain (Staphylococcus aureus, and on two yeasts: Candida albicans and Candida glabrata, which are the most frequently identified in clinical specimens, a mold: Aspergillus niger, and 5 dermatophytes: Microsporum canis, Microsporum gypseum, Trichophyton rubrum, Trichophyton mentagrophytes, and Epidermophyton floccosum.
\end{abstract}

Methods: The extraction of essential oils was carried out by steam distillation in a clevenger-type apparatus. The antimicrobial activity was determined by the disc diffusion method. The chromatographic analysis of HE five plants was performed with a gas chromatograph (GC) type Hewlett-Packard (6890) coupled to a mass spectrometer (HP5973).

Results: The results show that the essential oil of Teucrium capitatum L. has a large antimicrobial activity vis- $a$-vis other plants. Therefore, an identification of their chemical composition is necessary to identify the active molecules based on the analysis GC-only and coupled to mass spectrometry (GC-MS). The essential oil of the plant of T. capitatum L. of the region of El Hajeb (Morocco) was extracted to the study its performance, its chemical composition, and its property antibacterial and antifungal. The average content in essential oil of the leaves of this species is approximately $2 \%$ (wt.) of the total weight of dry matter. The chromatographic analysis showed the profiles, and the rates of the different components compared to the available standards, as function of the retention time by ascending order, four compounds were identified by GC and GC/MS as the main compounds of this oil: Endo-borneol (33\%), naphthalene, 1, 2, 3, 5, 6, 8a-hexahydro-4,7-dimethyl-1-(1-methyl ethyl)-, (1s-cis)-(19.63\%), bronyle acetate (15.56\%), alpha-terpineol (11.96\%), bicyclo[3.1.0]hexan-3-ol, 4-methyl-1-(1-methylethyl)-(10.94\%) among other 21 compounds.

Conclusion: This study allows, once again, the development of the exploitation of the essential oils in the areas, pharmaceutical and medicines and works the doors of the exploitation of these plants in the pharmaceutical market.

Keywords: Teucrium capitatum L., Ethnobotanical study, Antifungal activity, Chromatography.

(C) 2017 The Authors. Published by Innovare Academic Sciences Pvt Ltd. This is an open access article under the CC BY license (http://creativecommons. org/licenses/by/4. 0/) DOI: http://dx.doi.org/10.22159/ajpcr.2017.v10i2.14504

\section{INTRODUCTION}

The essential oils are complex mixtures consisting of several tens, see more than a hundred compounds, primarily of terpenes. These are constructed from several isoprene entities, constituting a very diverse family both at the structural level that functional [1].

Several studies on the bacteriostatic effect, spasmolytic and antiinflammatory of Teucrium are reported in the literature. This effect is probably due to the presence of several monoterpenes of cyclopentanoide in their essential oil [2].

The genus Teucrium originates from the most important genera of the Lamiaceae family. This genus is distributed in 340 species and varieties surroundings. From the point of view of taxonomic, they are identifiable thanks to the form of the calyx and inflorescence [3]. It is a large genus which differs from the other than in its corollas formed of an upper lip cotter and stamens restated above this slot so that the corolla seems only to have a lower lip to five lobes [4]

A large number of works have been published recently on the taxonomy of the genus based on morphological studies (itiorescences and calyx) [5], micromorphological, (trichomes) [2], but the relations within the group remain confused [6].
The genus Teucrium is very used in traditional pharmacopoeia since more than 2000 years [5], in many regions of the worlds. The pharmacological properties of some species of this genus have been demonstrated in scientific studies. The diseases for which these species are used are very diverse. We can mention: Their traditional uses in the symptomatic treatmentofdigestive disorders andin that ofStates neurotoniques of adults and children in particular in the case of minor disorder of sleep [1]. The species of Teucrium are bitter and astringent [7,8], used as antirheumatic diuretic, diaphoretic, tonic, antipyretic, and antispasmodic. Many of them are used in popular medicine as anti-inflammatory, antihypertensive, and anorexia [2], as well as antidiabetic medicine, antiseptic, anthelmintic, and carminative [9]. The species Teucrium montbretii is traditionally used as healing, anti-inflammatory and in the treatment of cancer. The antioxidant activity has also been demonstrated [7]. Several studies on the antimicrobial activity, smooth muscle relaxants, antipyretics, and anti-inflammatory drugs were conducted on Teucrium marum $[1,10]$. The study of Eisner et al. has shown that some monoterpenes contained in $T$. marum, exercise an activity anti-insecticide. Of even some work is state of treatment of malaria, in the past $[11,12]$

\section{Previous work on Teucrium polium}

The species T. polium L. (Lamiaceae) has been the subject of several investigations during these years [13]. These surveys have revealed the 
presence of different classes of compounds such as esters of fatty acids, the diterpenes, monoterpenes, the sesquiterpenes, the polyphenols, and flavonoids (cirsimaritine, cirsilol, cirsilineol, 5-hydroxy-6,7,3', 4'-tetraméthoxyflavone, salvigenine, apigenine- 5-galloylglucoside, apigenin-7-glucoside, vicenine, and luteolin-7-glucoside) [14]. Unlike other species of genus Teucrium which have been the subject of numerous studies, a bibliographic research thrust has demonstrated in a unique way, the absence of antimicrobial studies and chemical analyzes of the subspecies Teucrium capitatum.

\section{METHODS}

\section{Collection and preparation of samples}

The plant material is constituted of the integer part, harvested at different places in the region of El Hajeb in three periods (May; June; August). The samples dried in the shelter of the light and the humidity, at ambient temperature after drying.

\section{Hydrodistillation}

The extraction of essential oils has been carried out by hydrodistillation in a device of type Clevenger, $100 \mathrm{~g}$ powder of plant material with $500 \mathrm{ml}$ of water has been distilled for $3 \mathrm{hrs}$. The performance has been determined for each plant. The essential oil has been stored at $4^{\circ} \mathrm{C}$ in dark in the presence of sodium sulfate anhydrous.

\section{Chromatographic analysis}

The chromatographic analysis of the he has been carried out with a gas chromatograph type Hewlett-Packard (6890) coupled to a mass spectrometer (HP5973). The fragmentation is performed by electron impact to $70 \mathrm{EV}$. The column used is a capillary column HP - $5 \mathrm{~ms}(30 \mathrm{~m} \times 0.25 \mathrm{~mm}$ ). The thickness of the film is to $0.25 \mu \mathrm{m}$. The temperature of the column is scheduled from $20^{\circ} \mathrm{C}$ to $230^{\circ} \mathrm{C}$ to reason to $20^{\circ} \mathrm{C} / \mathrm{min}$. The carrier gas is helium whose flow is fixed at $1.5 \mathrm{ml} / \mathrm{min}$. The mode of injection is the split mode (report of leak: 1/70). The device is connected to a computer system managing a library of mass spectrum NIST 98 and controlled by software "HP Chemstation" allowing to follow the evolution of the chromatographic analyzes.

The identification of the components has been made on the basis of the comparison of their indices of retention with those of compounds standards of the computerized data bank (NIST 98) (Table 1).

\section{RESULTS AND DISCUSSION}

\section{Chemical characterization}

Qualitative analysis

The chemical analysis has allowed to highlight some secondary metabolites. Table 2 contains the results of the chemical tests performed on the plant T. capitatum L. harvested in May.
According to these results, we note that the plant T. capitatum L., as other species of families Lamiaceae, is rich in various secondary metabolites.

\section{Extraction of essential oils}

The essential oil of yellowish color, of a very strong and persistent odor, has been obtained by hydrodistillation with a yield of extraction of $2 \%$.

The methods of analysis and identification employed during this study have helped to identify compounds (Table 3).

From the essential oil obtained from the plant T. capitatum L., 21 products have been able to be identified, which represents the essential oil. The results are shown on Table 1 . The majority compounds are: Endo-borneol (33\%), naphthalene,1,2,3,5,6,8a-hexahydro-4,7dimethyl-1-(1-methyl ethyl)-,(1s-cis)- (19.63\%), bronyle acetate (15.56\%), alpha-terpineol (11.96\%), bicyclo[3.1.0]hexan-3-ol,4methyl-1-(1-methylethyl)-(10.94\%).

\section{DISCUSSION}

The literature has shown a variation between the chemical compositions according to the geographical origin $[16,17]$ of the species. For example, myrcene (15.3\%), the germacrène D (9.0\%), the $\alpha$-pinene (6.6\%), and the $\alpha$-cadinol (5.1\%) were the main components of the essential oil of T. polium L. Tunisia [16]. The main compounds reported for T. polium of Iran have been the $\alpha$-pinene $(12.52 \%)$, the linalool $(10.63 \%)$, the oxide of caryophyllene $(9.69 \%)$, the $\beta$-pinene (7.09\%), and $\beta$-caryophyllene (6.98\%) [18]. The major compounds of T. polium of Algerian Northwest were the germacrène D (25.81\%), the bicyclogermacrene (13\%), the $\beta$-pinene $(11.69 \%)$, and carvacrol (8.93\%) [19]. The major compound of the essential oil T. polium Jordan being the 8-cedren-13-ol (24.8\%) [20]. In the case of the essential oil of T. polium also investigated by Hussain et al., 2013 [21], the percentages of majority compounds are the following: The ledeneoxyde (II) (20.47\%), acetate of linalyle (11.16\%), the $\beta$-eudesmol (11.59\%), and $\alpha$-trans-bergamatene (6.81\%).

The composition of the essential oils of the Lamiaceae is characterized by a large diversity between species. Each plant has its own fingerprints [22]

Hence, we can say that the composition of the essential oil of T. capitatum L. is characterized by the chemotype of the plant as in the case of other species aromatic. It also depends on the part of the plant used and its stage of growth as well as the nature of the soil and of the conditions of culture. The chemical composition of the essential oils of T. capitatum the samples studied is different from that of the other species, therefore, present a chemical polymorphism very important.

Table 1: Chromatographic assay protocol

\begin{tabular}{|c|c|c|}
\hline \multirow[t]{4}{*}{ Oven } & Injection temperature & $250^{\circ} \mathrm{C}$ \\
\hline & Temperature of the interface & $250^{\circ} \mathrm{C}$ \\
\hline & Initial temperature & $70^{\circ} \mathrm{C}$ \\
\hline & Rise in temperature & $20^{\circ} \mathrm{C} / \mathrm{min}$ \\
\hline \multirow[t]{4}{*}{ Column } & Characteristics of the column & VB-Wax (length $30 \mathrm{~m}$, ID $0.25 \mathrm{~mm}$, temperature limits $20-230^{\circ} \mathrm{C}$ ) \\
\hline & Vector gas & Helium \\
\hline & Split & Split flow (10 ml/minute) \\
\hline & & Split ratio 10 \\
\hline \multirow[t]{7}{*}{ Spectrometer de masse } & Temperature characteristics of the source & \\
\hline & Temperature of the quadrupole & $200^{\circ} \mathrm{C}$ \\
\hline & Mode of ionization & $200^{\circ} \mathrm{C}$ \\
\hline & Energy of collision & By electrons \\
\hline & Mass range (UMA) & $70 \mathrm{eV}$ \\
\hline & The ignition delay of the filament & $50-650$ \\
\hline & Temperature characteristics of the source & 3 minutes \\
\hline \multirow[t]{2}{*}{ Le solvent } & Solvent & Hexane \\
\hline & Dilution factor & $1 / 100$ \\
\hline
\end{tabular}


Table 2: Result of the chemical tests of the plant Teucrium capitatum $\mathrm{L}$.

\begin{tabular}{|c|c|c|}
\hline Nom des composes & Nom de test & Teucrium capitatum $\mathrm{L}$. \\
\hline The alkaloids & Mayer dragendorff & + \\
\hline Tannins & Diluted solution of ferric chloride & + \\
\hline Catechin tannins & Concentrated HCL & + \\
\hline Gallic tannins & Reaction of stiasny & + \\
\hline \multicolumn{3}{|l|}{ Flavonoids: } \\
\hline Anthocyanins & $\mathrm{H}_{2} \mathrm{SO}_{4} / \mathrm{NH}_{4} \mathrm{OH}$ & + \\
\hline Flavones and flavonoids free (genine) & Reaction to the cyanidin & + \\
\hline Leucoanthocyanes & Reaction to the cyanidin without mg & - \\
\hline Sterol and triterpenes & Chloroform/acetic anhydride/ $\mathrm{H}_{2} \mathrm{SO}_{4}$ & + \\
\hline Compounds reducers & Reagent of fehling & + \\
\hline Oses and holosides & $\mathrm{H}_{2} \mathrm{SO}_{4}$ /ethanol/thymol & - \\
\hline Cyanogenetique glycosides & Toluene & - \\
\hline Anthraquinone free & Chloroform $/ \mathrm{NH}_{4} \mathrm{OH}$ & + \\
\hline \multicolumn{3}{|l|}{ Anthraquinone combined: } \\
\hline O-glycosides & $\mathrm{HCL} / \mathrm{NH}_{4} \mathrm{OH}$ & - \\
\hline C-glycosides & $\mathrm{FeCl}_{2} / \mathrm{NH}_{4}^{4} \mathrm{OH}$ & \\
\hline Saponins & Index of foam* & - \\
\hline
\end{tabular}

Table 3: Chemical composition of essential oil of the Teucrium capitatum $\mathrm{L}$.

\begin{tabular}{|c|c|c|c|}
\hline IR & Constituents & Formula & Percentage \\
\hline 4.02 & 2',4'-dihydroxyacetophenone & $\mathrm{C}_{8} \mathrm{H}_{8} \mathrm{O}_{3}$ & 0.28 \\
\hline 4.16 & Bicyclo[3.1.0]hexan-3-ol, 4-methyl-1-(1-methylethyl)- & $\mathrm{C}_{10}^{8} \mathrm{H}_{18}^{8} \mathrm{O}$ & 10.94 \\
\hline 4.40 & Endo-borneol & $\mathrm{C}_{10}^{10} \mathrm{H}_{18}^{18} \mathrm{O}$ & 33.00 \\
\hline 4.57 & Alpha-terpineol & $\mathrm{C}_{10}^{10} \mathrm{H}_{18}^{18} \mathrm{O}$ & 11.96 \\
\hline 4.81 & Bicyclo[3.1.1]hept-3-en-2-ol, 4,6,6-trimethyl-,[1S-(1à,2á,5à)]- & $\mathrm{C}_{10}^{10^{2}} \mathrm{H}_{18}^{18} \mathrm{O}$ & 0.26 \\
\hline 5.24 & Bronyle actate & $\mathrm{C}_{10}^{10} \mathrm{H}_{14}^{18} \mathrm{O}$ & 15.56 \\
\hline 5.42 & Phenol, 2-methyl-5-(1-methylethyl)- & & 0.88 \\
\hline 5.52 & Fumaric acid, dimyrtenyl ester & $\mathrm{C}_{24} \mathrm{H}_{32} \mathrm{O}_{4}$ & 0.40 \\
\hline 5.93 & Copaene & $\mathrm{C}_{10}^{24} \mathrm{H}_{18}^{32} \mathrm{O}$ & 0.45 \\
\hline 6.00 & Alpha-ylangene & $\mathrm{C}_{15}^{10} \mathrm{H}_{24}^{18}$ & 0.32 \\
\hline 6.26 & 1S,2S,5R-1,4,4-trimethyltricyclo[6.3.1.0 (2,5)]doc-8 (9) ene & $\mathrm{C}_{10}^{15} \mathrm{H}_{18}^{24} \mathrm{O}$ & 0.42 \\
\hline 6.75 & Longifolene & $\mathrm{C}_{15}^{10} \mathrm{H}_{24}^{18}$ & 0.34 \\
\hline 6.18 & Retinoic acid, methyl ester & $\mathrm{C}_{21}^{15} \mathrm{H}_{30}^{24} \mathrm{O}_{2}$ & 0.70 \\
\hline 6.90 & Naphthalene, 1,2,3,5,6,8a-hexahydro-4,7-dimethyl-1-(1-methyl ethyl)-, (1S-cis)- & $\mathrm{C}_{15}^{21} \mathrm{H}_{24}^{30}$ & 19.63 \\
\hline 7.12 & Retinol & $\mathrm{C}_{20}^{15} \mathrm{H}_{30}^{24} \mathrm{O}$ & 0.98 \\
\hline 7.86 & 2-(4a, 8-dimethyl-1,2,3,4,4a, 5,6,7 octahydro-naph thalen-2-yl)-prop-2-en-1-ol & $\mathrm{C}_{15}^{20} \mathrm{H}_{24}^{30} \mathrm{O}$ & 0.35 \\
\hline 8.12 & Ethyl 5,8,11,14,17-icosapentaenoate & $\mathrm{C}_{21}^{15} \mathrm{H}_{34}^{24} \mathrm{O}_{2}$ & 0.40 \\
\hline 8.26 & 3,5-androstadien-17-one oxime & $\mathrm{C}_{10}^{21} \mathrm{H}_{18}^{34} \mathrm{O}^{2}$ & 0.59 \\
\hline 8.58 & Butyl 4,7,10,13,16,19-docosahexaenoate & $\mathrm{C}_{23}^{10} \mathrm{H}_{34}^{18} \mathrm{O}_{2}$ & 0.51 \\
\hline 8.76 & Pregnenolone & $\mathrm{C}_{21}^{23} \mathrm{H}_{32}^{34} \mathrm{O}_{2}^{2}$ & 0.40 \\
\hline \multirow[t]{2}{*}{8.97} & Aromadendrene, dehydro- & & 0.30 \\
\hline & Total & & $98.56 \%$ \\
\hline
\end{tabular}

\section{Relationship antimicrobial activity/active principles}

The great diversity of the structures and functions of terpenoids has caused an interest for their use in traditional medicine and modern. The usefulness of terpenoids has been demonstrated for the chemoprevention and chemotherapy of several diseases [22,23] and also for antimicrobial properties, antifungal, pest control, antiviral, antioxidant, anti allergènes, antispasmodics, antineoplastic antihyperglycémiques, anti-inflammatory, and immunomodulating [24].

According to the study antifungal drug [25], it was found that the essential oil of T. capitatum has a large antibacterial activity with diameters of inhibition varies between $40 \mathrm{~mm}$ and $43 \mathrm{~mm}$. It has exercised a significant inhibitory activity vis-a-vis all fungal, the strains Trichophyton rubrum and Trichophyton mentagrophytes, and Epidermophyton floccosum were inhibited completely from the minimum concentration of $32.26 \mathrm{ul} / \mathrm{ml}$, and for strains Microsporum gypseum and Candida glabrata from $20.41 \mathrm{ul} / \mathrm{ml}$, whereas the concentration of $15.87 \mathrm{ul} / \mathrm{ml}$ has been sufficient to stop the growth of Candida albicans, Microsporum canis, and Aspergillus niger, the results of each minimum concentration. The report of the minimum inhibitory concentration and the minimum concentration fungicide presented gave as a result that the plant of T. capitatum The exerts a fungicidal activity for all strains, after the results were chromatographic was able identified the major compounds that are known by their principles assets; The biological activity of the active principles natural between essential oils is linked to their chemotype, i.e., the or the biologically active molecules and predominantly present, their composition or the functional groups of the compounds in the majority (alcohol, phenols, and terpenic compounds ketone) and to their synergistic actions. This antibacterial activity of natural substances is explained by the lysis of the bacterial membrane; the He, flavonoids, the alkaloids or even the tannins could induce a leak of potassium ions at the membrane level and by way of the consequences of the irreversible lesions at the level of this membrane. This permeability to potassium effect is a precursor of their death [26], therefore, the high content of the essential oil in terpene alcohols, bornyl acetate, may explain the antifungal activity of the plants [27], and therefore, can be used as an antiseptic against the dermatophytes [28].

\section{CONCLUSION}

According to these results, the essential oil of the plant of T. capitatum showed a antimicrobial activity important on the strains studied. 
This activity can be attributed to the richness of the chemical composition of phenolic compounds. The results obtained are promising and encouraging because there is a strong correlation: Active compounds/antifungal activity

\section{REFERENCES}

1. Bruneton J. Pharmacognosie Phytochimie Plantes Médicinales. $3^{e}$ éd. Paris: Tec et Doc.;1999.

2. Ricci D, Fraternale D, Giamperi L, Bucchini A, Epifano F, Burini G, et al. Chemical composition, antimicrobial and antioxidant activity of the essential oil of Teucrium marum (Lamiaceae). J Ethnopharmacol 2005:98(1-2):195-200

3. Grubesic RJ, Vladimir-Knezevic S, Kremer D, Kalodera Z, Vukovic J. Trichome micromorphology in Teucrium (Lamiaceae) species growing in Croatia. Biol Bratisl 2007;62(2):148-56.

4. Ozenda P. Flore du Sahara. $2^{\mathrm{m}}$ ed. Paris: CNRS; 1977.

5. El-Oualidi J. Biosystematics and Taxonomy of the Teucrium of the Polium Section (Lamiaceae) In the Western Mediterranean Basin. Different Aspects of Variation in Morocco, France and Spain.Thesis PhD. France: University of Montpellier; 1991.

6. Harborne JB, Tome-Barberan FA, Williams CA, Gil MI. A chemotaxonomic study of flavonoids from European Teucrium species. Phyrochemiwy 1986;25(12):2811-6.

7. Özkan G, Kuleaoan H, Çelik S, Gokturk RS, Ünal O. Screening of Turkish endemic Teucrium montbretii subsp. Pamphylicum extracts for antioxidant and antibacterial activities. Food Control 2007;18:509-12.

8. Abdollahi M, Karimpour H, Monsef-Esfehani HR. Anti nociceptive effects of Teucrium polium L. total extract and essential oil in mouse writhing test. Pharmacol Res 2003;48:31-5.

9. Gharaibeh MN, Elayan HH, Salhab AS. Hypoglycemic effects of Teucrium polium. J Ethnopharmacol 1988;24(1):93-9.

10. Eisner T, Eisner M, Aneshansley DJ, Wu CL, Et Meinwald J. Chemical defense of the mint plant, Teucrium marum. Chemoecology 2000;10:211-6

11. Camarda I. Ricerche etnobotaniche nel comune di Dorgali, Sardegna centro orientale. Boll Soc Sarda Sci Nat 1990;27:147-204

12. Vokou D, Margaris NS. Variation of volatile oil concentration of mediterranean aromatic shrubs Thymus capitatus Hoffmag et link, Satureja thymbra L., Teucrium polium L. and Rosmarinus officinalis. Int J Biometeor 1986;30(2):147-55

13. Hasani P, Yasa N, Vosough-Ghanbari S, Mohammadirad A, Dehghan G, Abdollahi M. In vivo antioxidant potential of Teucrium polium, as compared to alpha-tocopherol. Acta Pharm 2007;57(1):123-9.

14. Velasco-Negueruela A, Perez-Alonso MJ. The volatiles of six Teucrium species from the Iberian Peninsula and the Balearic Islands. Phytochemisry 1990;29(4):1165-9.

15. Boulila A, Béjaoui A, Messaoud C, Boussaid M. Variation of volatiles in Tunisian populations of Teucrium polium L. (Lamiaceae). Chem Biodivers 2008;5(7):1389-400.

16. Bakkali F, Averbeck S, Averbeck D, Idaomar M. Biological effects of essential oils - a review. Food Chem Toxicol 2008;46(2):446-75

17. Moghtader M. Chemical composition of the essential oil of Teucrium polium L. from Iran. Am Eurasian J Agric Environ Sci 2009;5(6):843-6.

18. Belmekki N, Bendimerad N, Bekhechi C, Fernandez X. Chemical analysis and antimicrobial activity of Teucrium polium L. essential oil from Western Algeria. J Med Plants Res 2013;7(14):897-902.

19. Hilan C, Sfeir R, Jawish D, Aitour S. Essential oils of certain Lebanese medicinal plants of the Lamiaceae family. Liban Sci J 2006;7(2):13-22.

20. Aburjai T, Hudaib M, Cavrini V. Composition of the essential oil from Jordanian Germander (Teucrium polium L.). J Essent Oil Res 2006;18:97-9.

21. Hussain J, Rehman NU, Al-Harrasi A, Ali L, Khan A, Albroumi AM. Essential oil composition and nutrient analysis of selected medicinal plants in Sultanate of Oman, Asian Pac J Trop Dis 2013;3(6):421-8.

22. Jennewein, S, Croteau, R. Taxol: Biosynthesis, molecular genetics, and biotechnological applications. Appl Microbiol Biotechnol 2001;57:13-9.

23. Rodríguez-Concepción M. The MEP pathway: A new target for the development of herbicides, antibiotics and antimalarial drugs. Curr Pharm Des 2004;10(19):2391-400.

24. Paduch R, Kandefer-Szerszen M, Trytek M, Fiedurek J. Terpenes: Substances useful in human healthcare. Arch Immunol Ther Exp (Warsz) 2007;55(5):315-27.

25. Jalila El amri, Khalid El Badaoui, Touria Zair, Hayate Bouharb, Saïd Chakir, Taj lmolk Alaoui, Redouane Tarik, 2015. Study of the antifungal Activity of Six plants: Teucrium capitatium L, Thymus cilitatus, Silene vulgaris, Origanum compactum, Anthemis nobilis and Rosmarinus officinalis. Chem Sci Rev Lett, 4(16), 1285-1292.

26. Salah B, Ouahiba B, Boutlelis DA. Laboratory of plant biology and (LBVE). Algiers J Arid About 2013;3(2):15-23

27. Keita A. Terpenes of the essential oil of the inflorescences of (This Kala) Cymbopogon anleus Chiov. Med Afr Black 1993;40(4):423-8.

28. Chaumont JP, Leger D. Antifungal properties of some phenols and chemically very similar compounds. Activity structure relationship. Plant Med Phyto 1989; 21(U2):124-6. 